\title{
Utmaning eller tillgång? Att undervisa modersmålstalare i språkutbildning på universitetet
}

\author{
Ingela Johansson ${ }^{*, a}$ och Gudrun Seiler-Holmer ${ }^{\mathrm{b}}$ \\ ${ }^{a}$ Lunds universitet och ${ }^{b}$ Gymnasielärare, Lund
}

\begin{abstract}
I språkutbildning vid svenska lärosäten finns det vanligtvis ett antal studenter i varje grupp som har det studerade språket som modersmål (LI), även om majoriteten utgörs av studerande som läser språket som främmande språk (L2). I vår studie undersöker vi erfarenheter av att undervisa denna typ av grupp genom semistrukturerade intervjuer med sex universitetslärare i franska, spanska och tyska. Undersökningen visar att lärarna mestadels ser LI-studenterna som en tillgång för gruppen, samtidigt som de är medvetna om risken att dessa blir alltför tongivande. Det framgår också att LI-studenterna, majoriteten med högskolestudier från hemlandet, överlag accepterar att de måste läsa sitt modersmål tillsammans med L2-inlärare för att bli lärare i svensk skola.
\end{abstract}

Nyckelord: språkinlärning, L1-talare, L2-inlärare, blandade grupper, heritage students

\section{INLEDNING}

I universitetsutbildningar i de vanligaste skolspråken (engelska, franska, spanska, tyska) vid svenska lärosäten finns det så gott som alltid några studenter som har språket $\mathrm{i}$ fråga som modersmål (Li-studenter). ${ }^{\mathrm{I}}$ Dessa studerar alltså sitt eget språk i grupper där majoriteten läser språken som främmande språk, och alltså är L2-studenter. ${ }^{2}$ I föreliggande studie vill vi undersöka språkundervisning och språkstudier i sådana heterogena grupper, främst ur lärarnas perspektiv men, som ett komplement, även ur de modersmålstalande studenternas synvinkel. Vi undersöker i vilken utsträckning universitetslärare i språk reflekterar över den didaktiska situationen i denna typ av grupp och anpassar sin planering och undervisning efter gruppsammansättningen.

I Sverige undervisas engelska från och med grundskolans tredje klass och räknas inte in i skolämnet Moderna språk. Vi koncentrerar oss därför på franska, spanska och tyska, som har en jämförbar ställning i svensk utbildning. Dessa tre är de vanligast förekommande moderna språken i grundskolan och de enda som kommunerna enligt skollagen måste erbjuda eleverna från årskurs 6: "Huvudmannen ska som språkval erbjuda minst två av språken franska, spanska och tyska" (SFS, 20II, s. I85). ${ }^{3}$

1 Modersmålstalare kommer i vår text att benämnas L1-talare eller L1-studenter.

2 Med L2 avser vi ett främmande språk, oavsett om den studerande lär det som språk två, tre, fyra eller mer i ordningen. L2-studenten kommer ibland även att benämnas L2-inläraren.

3 Kunskaper i "modersmålet plus två" ses som en demokratifråga i EU:s språkpolitik (Europeiska kommissionen, 2008, s. 5).

*Författarkontakt: ingela.johansson@rom.lu.se

Artiklar och reflektioner är kollegialt granskade. Övriga bidragstyper granskas av redaktionen. Se www.hogreutbildning.se ISSN 2000-7558

(C)2019 Ingela Johansson och Gudrun Seiler-Holmer. This is an Open Access article distributed under the terms of the Creative Commons Attribution-NonCommercial 4.0 International License (https://creativecommons.org/licenses/by-nc/4.0/), allowing third parties to share their work (copy, distribute, transmit) and to adapt it, under the condition that the authors are given credit, that the work is not used for commercial purposes, and that in the event of reuse or distribution, the terms of this license are made clear.

Citation: Ingela Johansson och Gudrun Seiler-Holmer (2019) «Utmaning eller tillgång? Att undervisa modersmålstalare i språkutbildning på universitetet), Högre utbildning, 9(1), 60-77. http://dx.doi.org/10.23865/hu.v9.1471 
Även i svensk högskoleutbildning har franska, spanska och tyska en likartad ställning, och enligt en preliminär observation uppvisar gruppsammansättningen vad gäller språkbakgrund påfallande likheter: $\mathrm{i}$ grundutbildningen i samtliga språk finns en majoritet L2-studenter och oftast någon eller några Li-studenter. Därutöver finns ett inslag av studenter som tillhör gruppen arvspråkstalare, heritage speakers, alltså personer med viss kompetens i föräldrarnas första språk. I en undervisningssituation inom ramen för språkstudier på universitetsnivå har läraren alltså normalt att hantera språklig kompetens av mycket varierande grad, från personer i stort behov av färdighetsträning till sådana som har full målspråkskompetens. Det tål att poängteras att språkstudier på universitetet är av en annan art än gymnasiets och språkskolornas, i det att språklig färdighet framför allt är ett medel för att tillägna sig kunskaper om respektive språkområdes historia, samhällsliv och kulturella uttryck, främst litteratur, och för att på avancerad nivå kunna analysera och reflektera över dessa i tal och skrift. Även själva språket studeras på teoretisk nivå. Den språkliga kompetensen påverkar dynamiken mellan studenterna och blir avgörande för hur en undervisningssituation avlöper. För att undersöka hur lärarna upplever att denna typ av heterogen grupp fungerar har vi gjort djupintervjuer med två lärare från vart och ett av de nämnda språken. I syfte att belysa situationen ur ett studerandeperspektiv har vi också genomfört en enkätstudie med I2 studerande som har franska, spanska eller tyska som modersmål.

I följande avsnitt går vi närmare in på tidigare undersökningar inom detta forskningsområde, syftet med vår studie samt begrepp och metod, innan vi presenterar våra resultat.

\subsection{Få studier om modersmålstalande i svensk högre utbildning}

Få svenska studier belyser undervisningssituationen i grupper där LI-talare och L2-inlärare blandas i högskoleutbildning i språk. De undersökningar som gjorts härrör främst från USA, Kanada och Australien. Här kan till exempel nämnas antologin The sociolinguistics of foreign language classrooms: contributions of the native, the near-native, and the non-native speaker (Blyth, 2003), som främst behandlar spanska och franska som språkämnen i USA. Den kategori som beforskats i störst utsträckning tycks vara arvspråkstalare. Som tidigare nämnts är en arvspråkstalare en person vars föräldrar talar ett annat språk än landets majoritetsspråk; ett arvspråk är enligt Valdés (1995; 2005) ett språk som talas av personer tillhörande en samhällelig minoritet, och det kan röra sig om både ursprungsbefolkningar och inflyttade grupper. ${ }^{4}$ Arvspråkstalare är till en viss grad tvåspråkiga, och en gemensam nämnare är att de månar om sitt språkliga arv (Valdés, 2005)..$^{5}$ I utbildningskontext avser arvspråkstalare främst personer som studerar ett språk som de lärt sig och använder i hemmet (Valdés, 2005, s. 4II-4I2). Som grupp har de en mycket varierad språkbakgrund och därmed olika kompetensnivå, vilket har gjort det svårt att tillgodose deras behov i L2-klassrummet (Alarcón, 20IO; Torres et al., 20I7). Därför har man i USA utvecklat kurser specifikt för vissa grupper av arvspråkstalare, främst de spansktalande och kinesiska. I Australien gäller detta för bland annat grekiska, italienska och kinesiska (Elder, 2000). Kurserna kan jämföras med vårt svenska ämne Modersmål. ${ }^{6}$

Edstrom (2007) uppmärksammar det faktum att det är lättare att skilja mellan kategorierna LI-talare och L2-inlärare än mellan LI-talare och arvspråkstalare. De olika kompetensnivåerna

4 I australiensisk forskning benämns dessa ofta background language speakers (Valdés, 2005, s. 412), men vi väljer att använda den vanligare termen heritage speakers.

5 Definitionen av arvspråk har blivit omdiskuterad. För en genomgång av olika perspektiv, se Polinsky, M. \& Kagan, O. (2007).

6 I svensk skolkontext råder en viss begreppsförvirring eftersom skolämnet Modersmål främst riktar sig till elever som i forskningen definieras som arvspråkstalare. 
kan försvåra språkundervisningen men, enligt flera studier citerade av Edstrom, drar språkstuderande i det heterogena klassrummet också nytta av varandras kunskaper och förmågor. De undersökningar som kommit fram till detta resultat ägnar emellertid främst uppmärksamhet åt språkkurser på lägre nivå, varför Edstrom vill bidra med en studie av mer avancerade universitetskurser. Edstrom undersöker med hjälp av en enkät och efterföljande intervjuer en mindre grupp spanskstudenter (I6 stycken) i "upper-level" vid ett amerikanskt universitet. I gruppen finns tio LI-talare, två arvspråkstalare och fyra L2-studenter. I studien framkommer att L2studenterna var övervägande positiva till att läsa spanska tillsammans med spanskspråkiga. De tyckte alla att de fick en bättre hörförståelse, och de uppmärksammade att de fick höra olika varieteter av spanska. Majoriteten tyckte att de fick en bättre kulturell kompetens. Alla menade att de spansktalande var respektfulla men en av deltagarna kände sig hämmad av de spanskspråkigas närvaro. Vidare befarade två av de fyra L2-studenterna att gruppens sammansättning höjde lärarens förväntningar på dem. Gruppen som bestod av arvspråkstalare och infödda talare var överlag positivt inställd till sina studier tillsammans med L2-studenter; bara två av de tillfrågade tyckte att det var negativt att blanda olika språkkompetenser i samma grupp. Flera av de spanskspråkiga trodde emellertid att L2-inlärarna blev hämmade av deras närvaro. Edstroms resultat pekar på att det tycks finnas fler fördelar än nackdelar med grupper som består av både Li-studenter, arvspråkstalare och L2-studenter. De positiva effekter som framkom var att L2-studenterna fick rik kulturell och språklig input och färdighetsträning, medan modersmålstalarna betonade att de uppskattade L2-inlärarnas förmåga att förklara grammatiska och fonetiska regler. Indirekt lärde de sig också vad som utgör svårigheter för engelskspråkiga när de lär sig spanska, vilket speciellt de som skulle bli lärare framhöll som en viktig kunskap. Edstroms studie är av stor relevans för vår, även om dess fokus är studentperspektivet medan vi utgår från lärarnas erfarenheter.

Ytterligare en studie vars frågeställning delvis sammanfaller med vår är López Garcías (2017), som liksom Edstroms utgår från situationen i USA och riktar in sig på hur arvspråkstalare i spanska upplevt att studera spanska tillsammans med personer som är enbart engelsktalande. Utgångspunkten är att de har andra behov än L2-studenterna då de mest använder spanskan $\mathrm{i}$ informella situationer, med familjen och i sin spansktalande kommunitet, och ibland saknar teoretiska språkkunskaper (20I7, s. I28). I ljuset av detta riktar López García ett antal frågor rörande erfarenheten av blandade grupper till 19 arvspråkstalare och 25 engelsktalande som studerar spanska vid universitetet i Granada i Spanien. Studien visar att båda grupperna tyckte sig få bredare lingvistiska och kulturella kunskaper genom att läsa tillsammans. Arvspråkstalarna menade förvisso att de redan behärskade mycket av kursinnehållet, men underströk att de engelsktalande hade bättre formella kunskaper. López Garcías undersökning har gemensamma drag med vår men koncentrerar sig på studenterna och inte på lärarperspektivet. ${ }^{7}$

Svensson (2017) undersöker det heterogena klassrummet $\mathrm{i}$ en studie av engelskämnet på gymnasiet. Fem gymnasielärare intervjuas för att ge sin bild av arbetet med att individualisera undervisningen. Merparten fann att elevernas mycket varierande engelskkunskaper är en stor utmaning: många elever får mycket input på engelska via olika kulturyttringar, sociala media och dataspel, medan andra inte tar del av detta i lika stor utsträckning. De som får mycket input utvecklar goda färdigheter framför allt muntligt och inom hörförståelse. Dessa elever måste stimuleras för att undervisningen ska utveckla dem inom de områden där de fortfarande har mycket att lära, samtidigt som läraren måste se till att de mindre högpresterande utmanas på en lagom nivå och inte får alltför svåra uppgifter. Vad gäller frågan om heterogenitet inom

7 För en översikt över internationella studier inom forskningsområdet, se Abdi (2009, s. 29-32). 
en undervisningsgrupp i språk är denna studie relevant för vår. En skillnad i förutsättningar är emellertid att styrdokumenten för gymnasieskolan påbjuder individualisering av undervisningen, medan lärarna på universitetskurser i språk inte på samma sätt är bundna att möta varje student på dess nivå, utan erbjuder en kurs där vissa mål ska uppnås med utgångspunkt $\mathrm{i}$ L2-studenternas behov.

En annan studie som behandlar företeelsen kompetensmässig heterogenitet i språkstudier i svensk kontext är Seiler-Holmers (20I4). Genom djupintervjuer undersöker hon gymnasielärares erfarenheter av grupper i fem språk, nämligen franska, italienska, kinesiska, spanska och tyska, där det finns elever som har språket i fråga som modersmål. Det visar sig att gymnasielärarna är mycket medvetna om problematiken med olika språkbakgrund och varierande färdighetsnivåer, men att frågan sällan diskuteras annat än när praktiska arrangemang måste göras, till exempel vid särskild prövning. De intervjuade lärarna upplevde det som svårt att ge olika kategorier elever optimal undervisning, och såg det som en del av en större problematik, nämligen svårigheten att individualisera undervisningen. De jämförde problemet med det som uppstår i andra typer av heterogena grupper, exempelvis sådana där två språkkurser slagits ihop till en av ekonomiska skäl, och där läraren måste hantera två olika steg i ett och samma klassrum. Ett annat viktigt resultat av studien var att meritpoängsystemet, som inte ger meritpoäng för kurser i ämnet Modersmål, styr LI-eleverna mot att välja språkkurser på en för dem egentligen alltför låg nivå, anpassade efter L2-inlärare.

\subsection{L1 - en tillgång på högre nivå?}

Det var främst mot bakgrund av undersökningarna av språkundervisning i svensk gymnasieskola som vi utformade denna studie av språkundervisning på högskolenivå. Med tanke på att universitetsstudierna i språk skiljer sig från de framför allt språkfärdighetsinriktade kurserna i andra skolformer ville vi undersöka om lärarna ställs inför samma typ av svårigheter eller om de snarare upplever heterogena grupper som en tillgång. Vår hypotes var att de svårigheter som identifierades i Seiler-Holmers studie (2014) tenderar att avta i takt med studienivån. Med andra ord torde grupper med varierande språkbakgrund upplevas som mindre problematiska och mindre pedagogiskt-didaktiskt utmanande av lärare på universitetet än på gymnasiet, i synnerhet i mer avancerade kurser, eftersom L2-studenternas språkliga kompetens närmat sig LI-studenternas.

Även om vårt huvudfokus var lärarnas erfarenheter ville vi också belysa LI-studenternas motiv till att studera sitt språk i svensk högskola. Vi ville också undersöka om dessa, liksom deltagarna i Edstroms (2007) och López Garcías (2017) undersökningar, hade en övervägande positiv inställning till att studera tillsammans med L2-studenter.

\subsection{Språkstudier - behörighet och förkunskaper}

För språkstudier på universitetets grundkursnivå är det särskilda behörighetskravet gymnasieskolans Moderna språk 3. Den formellt förväntade språkkompetensen måste därmed sägas vara låg. Svenska elever exponeras för en riklig input av engelska, deras första främmande språk, inte bara i skolundervisningen utan även genom populärkulturen, från musik-, film- och spelvärlden (jfr Svensson, 20I7). När det däremot gäller deras andra främmandespråk, som de normalt börjar läsa år 6, begränsas inputen oftast till klassrummet, och de timmar lärarna förfogar över på grundskola och gymnasium räcker inte till för att ge eleverna den mångfacetterade språkliga kompetens som egentligen är nödvändig för att senare kunna bedriva akademiska studier i och på målspråket. Många av universitetets grundkursstudenter upptäcker att de krav som ställs i praktiken långt överstiger de formella. 


\section{Ingela Johansson och Gudrun Seiler-Holmer}

I språkklassrummet samsas alltså L2-studerande, som kan ha svårigheter att läsa längre texter och att kommunicera muntligt på målspråket, med Li-studenter, som förstås har ett stort försprång vad gäller språkfärdigheten, men som kan ha svårigheter med exempelvis de kontrastiva momenten. Därtill kommer arvspråkstalare som ofta har god muntlig förmåga men brister i det formella, en beskrivning som även stämmer in på personer som har bott länge i ett målspråksland. Kort sagt är undervisningsgrupperna i språk normalt sett heterogena, och det komplexa i gruppsammansättningen är något som universitetslärarna måste förhålla sig till dagligen.

\section{UNIVERSITETSLÄRARNAS ERFARENHETER AV HETEROGENA GRUPPER}

Nedan redogör vi för den intervjustudie som syftar till att belysa hur språklärare på universitetet planerar, genomför och upplever sin undervisning i grupper där LI-talare samsas med L2inlärare och där studenternas språkbakgrund alltså kraftigt varierar.

\subsection{Lärarperspektivet-metod, informanter, material}

För att belysa lärarperspektivet valde vi en kvalitativ metod och genomförde semistrukturerade djupintervjuer med sex universitetslärare, både adjunkter och lektorer. Intervjuerna följde en intervjuguide med frågor, men tilläts ta sina egna vägar om informanterna tog upp någon oförutsedd aspekt (jfr Bryman, 20II, s. 4I5). Våra frågor handlade om lärarnas syn på att ha LI-studenter och L2-studenter i samma grupp; vilka didaktiska krav den typen av grupp ställer på läraren; huruvida läraren anpassar undervisningen efter LI-studenterna; om läraren observerat att inslaget av modersmålstalare påverkar L2-studenterna och, slutligen, om detta är ett fenomen som uppmärksammas och diskuteras kollegor emellan.

Samtliga intervjuer gjordes med lärare anställda vid ett och samma lärosäte under försommaren 20I6. Kontakt med potentiella informanter togs via e-post där vi kort beskrev vår undersöknings syfte samt förklarade att deras medverkan var frivillig och tillförsäkrade dem anonymitet. Alla tillfrågade gav positivt svar till medverkan. Intervjuerna genomfördes huvudsakligen på arbetsplatsen, förutom en som av praktiska skäl genomfördes hemma hos informanten. Intervjuerna varade mellan 45 och 90 minuter. Tre av intervjuerna spelades in och transkriberades, medan de tre övriga av praktiskt-tekniska orsaker dokumenterades skriftligt under intervjuns gång. Anteckningarna sammanställdes omedelbart efter respektive intervjus genomförande. I tabell I nedan presenteras de intervjuade lärarna. Kön och ålder har vi betraktat som irrelevanta parametrar för vår undersökning, medan uppgifterna om första språk respektive yrkeserfarenhet vid intervjutillfället bedöms vara av intresse.

Tabell I. Intervjuade lärare

\begin{tabular}{|l|l|l|}
\hline Språk & Lärare I & Lärare 2 \\
\hline \multirow{2}{*}{ Franska } & A & $\mathrm{B}$ \\
& LI-talare & $\begin{array}{l}\text { L2-talare } \\
\text { Undervisningserfarenhet (svenskt lärosäte): } 20 \text { år }\end{array}$ \\
& Undervisningserfarenhet (svenskt lärosäte): 22 år ${ }^{8}$ & $\mathrm{D}$ \\
\hline \multirow{2}{*}{ Spanska } & $\mathrm{C}$ & L2-talare \\
& LI-talare & Undervisningserfarenhet (svenskt lärosäte): 8 år \\
\hline \multirow{2}{*}{ Tyska } & Undervisningserfarenhet (svenskt lärosäte): I3 år & F \\
& LI-talare & L2-talare \\
& Undervisningserfarenhet (svenskt lärosäte): I6 år & Undervisningserfarenhet (svenskt lärosäte): ca 25 år \\
\hline
\end{tabular}

8 Undervisningsår vid intervjutillfället. 
Som framgår av denna uppställning har vi valt att intervjua en LI-talare och en L2-talare från varje undersökt språk. Urvalet av informanter har varit målstyrt och har alltså skett utifrån våra forskningsfrågor (jfr Bryman, 20II, s. 434). Det är informanternas individspecifika utsagor som utgör det empiriska materialet i denna första undersökningsdel.

\subsection{Resultat}

Nedan redovisar vi resultatet av vår undersökning av lärarnas syn på blandade grupper. Vi har valt att fokusera dels på de punkter där informanternas utsagor huvudsakligen sammanfaller, dels på de frågor där utsagorna går tydligt isär. Utifrån detta kriterium strukturerar vi resultatredovisningen tematiskt, kring praktiska arrangemang, planering av undervisningen, genomförandet av densamma (här ingår utsagor om gruppdynamik) samt frågans aktualitet $i$ kollegiet.

\section{Delta eller inte delta?}

I de tre undersökta språkämnena, franska, spanska och tyska, måste LI-talarna enligt våra respondenter följa den vanliga undervisningen och inga specialarrangemang görs. Lärare E påpekar att studier i språk på universitetet i Sverige är främmandespråkstudier, vilket de flesta LI-studenter accepterar; de förstår att man för att vara yrkesverksam i Sverige behöver läsa sitt modersmål som främmandespråk. Flera av lärarna nämner dock att vissa Li-studenter ställer sig frågande till att delta i undervisningen på samma villkor som L2-talarna, eftersom de tycker att deras kunskaper borde befria dem från obligatoriet. Undantag görs i vissa fall, men endast vad gäller delkurser eller moment i muntlig språkfärdighet på grundkursnivå, där studenterna kan välja att inte delta i undervisningen utan bara avlägga muntligt prov. Lärarna i ämnen där undantag ibland görs för LI-studenter uppger emellertid att många av dessa väljer att faktiskt följa undervisningen ändå, eftersom de inser att även deras muntliga färdigheter kan utvecklas. Lärare A betonar att också målspråkstalarna kan vara betjänta av att träna såväl talteknik som retorik.

Det är endast delkurser i muntlig språkfärdighet som lärarna kan tänka sig att låta studenterna tentera av utan deltagande. Intressant nog framhåller L2-inlärarna i Edstroms (2007) studie betydelsen av LI-studenterna för utvecklandet av just den muntliga färdigheten, både för muntlig produktion och för reception, till exempel att uppfatta olika uttal. Detta var också en aspekt som lärarna i vår undersökning berörde i sina svar. Det framstår emellertid som att de av hänsyn till Li-studenterna inte fullt ut utnyttjar dem som den språkliga tillgång de kunde vara i klassrummet, kanske främst vad gäller muntlig språkfärdighet.

\section{Planeringen densamma, utfallet olika}

När det gäller undervisningsplaneringen har samtliga informanter den uttalade ambitionen att inte anpassa nivån efter LI-studenterna. Alla betonar att undervisningen ska vara likadan oavsett gruppsammansättning. Lärare A menar att det är viktigt att tidigt klargöra att det är LI-studenterna som ska anpassa sig efter L2-studenterna och inte tvärtom. Lärare B reflekterar dock kring att undervisningen ofta faller olika ut i språkligt heterogena grupper trots samma planering; närvaron av LI-studenter gör att föreläsningarna ofta tar sig andra vägar än de från början utstakade. Lärare $\mathrm{A}$ är inne på samma spår: hen låter bli att anpassa nivån efter LI-studenterna, men poängterar att det ibland är nödvändigt att vara mer påläst när det finns LI-studenter i gruppen, framför allt när det gäller kurser i realia, eftersom LI-studenterna ofta har mer gedigna samhällsoch historiekunskaper än L2-studenterna.

Lärare D uppger att det är lätt att ryckas med av LI-studenterna eftersom de ofta ger större gensvar, i så måtto att de vågar ta ordet när L2-inlärarna är mer försiktiga, och därför kan det 
lätt hända att man som lärare förleds att lägga sig på deras nivå. Enligt denna informant hände det oftare i början av lärarkarriären, medan hen numera på ett mer medvetet sätt anstränger sig för att Li-talarna inte ska bli alltför dominerande i undervisningen.

Reflektion och beprövad erfarenhet kan dock leda till att läraren vid behov anpassar sin undervisning efter respektive grupps sammansättning. Bland annat berättar lärare $\mathrm{C}$ att hen förklarar kulturella koder i målspråket på ett explicit sätt så att ingen av studenterna (varken LI- eller L2-talare) ska känna sig kunskapsmässigt utanför eller i underläge. Vidare understryker denna lärare att varken ett betydligt större ordförråd, god muntlig uttrycksförmåga eller en bredare sociokulturell kännedom om målspråket automatiskt innebär att en LI-talare förfogar över de nödvändiga akademiska kunskaperna för att lättare kunna klara sina högskolestudier än en L2-student. Tvärtom krävs det en viss insikt även hos LI-talare om att de, i likhet med L2studenterna, behöver träna textanalysförmåga samt skriftlig och muntlig färdighet på akademisk nivå för att lyckas med sina högskolestudier.

\section{Klassrumsdynamiken: en balansgång}

Forskning visar att en avgörande faktor vid språkinlärning är risktagande och låg nivå av ängslighet, något som främjas av en trygg social kontext (se t.ex. Ellis \& Shintani, 20I4). Trygghet är en förutsättning för aktivt deltagande och aktivt deltagande är i sin tur en framgångsfaktor i all inlärning (Weaver \& Qi, 2005, s. 570). Lärarna har därför en mycket viktig funktion i att skapa en klassrumsdynamik där studenterna känner sig tillfreds, slipper överdriven ängslan över att tappa ansiktet och får möjlighet att interagera med kurskamrater och lärare. När det gäller klassrumsdynamik och genomförande av undervisningen är våra informanter ur lärarkåren mycket medvetna om sin roll och om de problem som kan uppstå och som ställs på sin spets i mycket heterogena grupper. Som vi ska se nedan ser de trots detta Li-studenterna främst som en tillgång $\mathrm{i}$ språkklassrummet.

I den positiva vågskålen lägger samtliga att LI-talarna fungerar som en språkinlärningsresurs, i den bemärkelsen att L2-studenterna kan träna såväl hörförståelse som muntlig språkfärdighet i interaktion med dem. De består kurskamraterna med riklig språklig och kulturell input som de annars får i begränsad mängd i undervisningen. Informanterna i vår undersökning är i detta avseende helt samstämmiga med varandra och med studenterna i Edstrom (2007) och López García (2017).

Två av lärarna, $\mathrm{A}$ och $\mathrm{B}$, understryker att LI-studenterna oftast har större allmänbildning än L2-studenterna, och att det är nyttigt och inspirerande för de sistnämnda att se att den litteratur de läser eller de samhällsfrågor de diskuterar i undervisningen är en levande del av målspråkskulturen och inte något som bara existerar i klassrummet. Lärare B har noterat att det är lättare för studenterna att hitta motivationen när de träffar jämnåriga som redan är förtrogna med kursmaterialet, till exempel litteraturens klassiker, som de läst i skolan i sitt hemland: "Det är lättare för studenterna att förstå ... att det finns såna som är i samma ålder och läst de här verken i skolan. Verkliga människor som läst klassiker sedan högstadiet. Jag får bevis för att det är på riktigt. Det verkar mer intressant att höra det DE säger än det läraren säger. Mer verkligt.” På detta vis upplever lärarna att LI-studenterna är en källa till motivation för kurskamraterna.

Majoriteten av lärarna ser också LI-studenterna som en tillgång på lektionerna av det skälet att de agerar ett slags hjälpmotorer; de poängterar att undervisningen underlättas av att många LI-studenter pratar mycket och gärna. Lärare B tycker att det är betydligt lättare att undervisa när LI-studenter medverkar än i mer homogena grupper, för "jag slipper höra min egen röst". 
Baksidan av samma mynt är att LI-talarnas större muntliga förmåga och, ibland, initiativkraft lämnar mindre talutrymme åt L2-inlärarna. En aspekt av att blanda språkkompetenser i en grupp som diskuterats och undersökts av många är att de med sämre färdigheter kan komma att hämmas av de mer kompetenta (se t.ex. Katz, 2003). Edstrom (2007) undersökte denna aspekt i sin studie och fann att en av fyra L2-studenter upplevde att den hämmades av LI-studenterna medan de tre övriga inte alls kände så. I vår undersökning tar lärare $\mathrm{B}$ upp frågan till diskussion, men förhåller sig mycket skeptisk till att närvaron av LI-studenter automatiskt skulle hämma L2-studenterna. Enligt denna lärares erfarenhet är det snarare gruppstorleken som avgör hur mycket en tillbakadragen student vågar delta i diskussioner och samtal. Att gruppstorleken spelar stor roll bekräftas av många klassrumsforskare: en stor grupp gör att mer tillbakadragna - eller illa förberedda - studenter lättare kan gömma sig och förbli passiva, medan några få orädda personer får mycket talutrymme (Weaver \& Qi, 2005, s. 573).

Lärare A upplever förvisso att L2-studenterna kan vara rädda för att prata i närvaro av LIstudenterna, men detta sker främst i början av en kurs; ängsligheten brukar försvinna efterhand, och vår informant menar att L2-inlärarna snarare tycks känna sig uppmuntrade och motiverade mot slutet av kursen då de märker att de kan prata med en LI-talare. Denna lärare ser att L2studenterna blir djärvare allteftersom terminen fortskrider och noterar att de interagerar mer och mer med LI-talarna även utanför lektionssalen.

Lärare F använder LI-talarna som en resurs i undervisningen, inte minst som bollplank när det gäller termer, ord och uttryck i översättningsövningar. Denna lärare frågar dem ofta "Är det här OK?", "Finns det andra förslag på hur man kan säga?”. De flesta LI-studenter verkar tycka att det är givande att ha den rollen och informanten menar sig ha råkat ut för ytterst få personer under alla år som "tycker att de kan allt". Bara någon enstaka gång har en LI-student gått in i en alltför dominerande roll.

Detsamma tycker lärare A som ser LI-studenter som en stor tillgång i undervisningen. Ett par gånger har någon LI-talare tagit för stor plats i klassrummet, men oftast löser vår informant det problemet genom att ta upp saken direkt med studenten. Lärare B kan inte dra sig till minnes att någon LI-student varit för dominerande och därigenom stört undervisningen, utan ser bara fördelar: gruppen som helhet blir mer motiverad eftersom L2-studenterna har LI-studenterna som förebilder och strävar efter att uppnå samma flyt i språket och lika stora kunskaper om landet, litteraturen och kulturen.

Bland de mer negativa utsagorna finner vi en som grundar sig i en informants egna erfarenheter som språkstudent. Denna lärare betonar vikten av att man som gruppens ledare ser till att LI-studenterna inte dominerar på L2-studenternas bekostnad. Sin egen erfarenhet beskriver denna lärare såhär:

Jag kommer precis ihåg hur det var trots att det är 20 år sedan jag läste. Och jag kommer ihåg hur mycket jag irriterade mig på de modersmålstalande för att jag vet att jag tyckte att de fick alldeles för mycket utrymme och att de tog över alldeles för mycket så att konsekvensen av det blev att jag själv är rätt så känslig för det där.

Denna lärare vill sätta L2-studenterna i främsta rummet och säger sig vara beredd att gå långt för att de ska få den undervisning de är berättigade till: "Om det ska bli konfrontation på ett eller annat sätt [mellan LI-L2] då går jag hellre emot LI-studenterna för det är de som ska anpassa sig." Hur den didaktiska situationen fungerar menar vår informant är avhängigt 
den eller de modersmålstalandes individuella personlighet i samspel med kurskamraternas. Om LI-studenterna pratar mer än L2-studenterna så är det ett misslyckande från lärarens sida.

Även lärare $\mathrm{E}$ talar om betydelsen av klassrumsdemokrati och lärarens ansvar att fördela ordet på ett rättvist sätt, men detta har egentligen mindre med språklig bakgrund att göra än med den didaktisk-pedagogiska situationen i stort: även somliga L2-studerande kan breda ut sig på andras bekostnad. Om någon monopoliserar ordet är det ett tecken på att gruppdynamiken inte fungerar och då måste läraren ingripa. Lärare E försöker vara tydlig med att var och en av studenterna ska förstå sin roll och har inga problem med att säga att "nu får modersmålstalaren tagga ner lite och nu vill jag gärna höra vad de andra säger”.

Lärare C bidrar med en dimension som har med självbild och självkänsla att göra. Tidigt i karriären kunde denna lärare känna en viss lättnad vid kursstart över att se namn på grupplistorna som indikerade att det fanns modersmålstalare i kursen, eftersom det rimligen borde innebära att åtminstone några studenter med lätthet skulle klara den. Med tiden har vår informant dock ändrat uppfattning. Verkligheten är betydligt mer komplex, och läraren har identifierat några kategorier studenter som snarare får svårigheter att klara de mer teoretiska kurserna: dels rena Li-studenter, som kommit till Sverige i vuxen ålder, och arvspråkstalare med goda muntliga färdigheter, dels L2-studenter med goda språkfärdigheter som exempelvis bott länge $\mathrm{i}$ målspråkslandet eller lever ihop med en Li-talare. Enligt vår informants erfarenhet ligger problemet i att språket för dessa kategorier innan universitetsstudierna varit något naturligt, lätt och roligt, och att de, när de plötsligt tvingas anlägga ett vetenskapligt perspektiv och anstränga sig mer, upplever studierna som krävande och till och med får problem med självbilden, då de förstår att de har mycket kvar att lära. Dessa studenter kan ha svårt att ta emot lärarens kommentarer och anmärkningar: det kan "bli ett slag mot självkänslan och då kryper man ihop".

\section{Diskussion mellan kollegor}

Enligt de utsagor vi samlat in diskuteras fenomenet LI-talare i L2-undervisningen inte kollegor emellan annat än i enstaka fall. En informant uppger att frågan inte alls diskuterats och en annan att den bara tagits upp som ett administrativt spörsmål om hur mycket av undervisningen som ska vara obligatorisk för LI-talarna. Någon nämner att om LI-studenterna omtalas specifikt är det som individuella fall snarare än som en didaktisk utmaning. Det är inte ovanligt, enligt denne informant, att modersmålstalarna lämnar avtryck genom att de är färgstarka personligheter.

Denna utsaga stämmer väl överens med forskning som säger att äldre studenter är mindre ängsliga för att göra fel och mindre bekymrade över sin sociala roll i undervisningssituationen och att de därmed vågar exponera sig mer och visa sin personlighet (se t.ex. Weaver \& Qi, 2005, s. 577-578). Det är vanligt att de LI-studerande är äldre än L2-inlärarna, eftersom flertalet när de påbörjar sina språkstudier i Sverige redan har avklarade universitetsstudier i bagaget, vilket vår kartläggning visar (se nedan).

\section{Sammanfattning av undersökningen av lärarperspektivet}

Sammanfattningsvis visar vår studie av universitetslärares utsagor rörande språkundervisning $\mathrm{i}$ grupper med såväl LI- som L2-studenter att lärarna är mycket medvetna om att deras primära uppgift är att tillgodose L2-studenternas behov. De flesta ser både för- och nackdelar med att ha LI-talare i undervisningen, men övervägande delen är positiv och tycker att det antingen är oproblematiskt eller en tillgång, i många avseenden en stor tillgång. Av dem som är främst positiva betonas att LI-studenterna fungerar som ett slags motor i kurserna eftersom de oftare vågar 
uttrycka sig muntligt och inte sällan har större språkliga och kulturella kunskaper. Bland de utsagor som är delvis negativa finns att klassrumsdemokratin kan vara svårare att upprätthålla i heterogena grupper, eftersom det är lätt som lärare att ryckas med av LI-studenternas goda språkfärdigheter och andra kunskaper och erfarenheter och i stunden glömma bort vilken nivå kursen egentligen bör hållas på. En annan sida av saken som framkommer i undersökningen är att det är lätt att som lärare överskatta Li-studenternas akademiska förmågor och att inte tillräckligt uppmärksamma deras behov av träning i att anamma ett teoretiskt förhållningssätt.

Utifrån vårt insamlade material sluter vi oss till att beträffande lärarperspektivet stämmer till största delen vår hypotes (jfr I.2) att blandade grupper tycks bli en allt mindre didaktisk utmaning i takt med att studienivån blir högre. Lärarna uppger visserligen att LI-studenternas närvaro bidrar till att skapa olika nivåer inom samma grupp men detta upplevs inte som en större svårighet än den heterogenitet som kan finnas i universitetsklassrummet oaktat studenternas språkbakgrund.

\section{DE MODERSMÅLTALANDE STUDENTERNAS PERSPEKTIV}

Vid sidan om huvudsyftet att undersöka universitetslärarnas erfarenheter av heterogena grupper har vi velat få en bild av vilka LI-studenterna är och på vilket sätt deras upplevelse av studierna förhåller sig till det lärarna uppger i intervjumaterialet. Eftersom antalet Li-studenter i de tre språk vi intresserar oss för är mycket litet vid ett och samma lärosäte genomförde vi en digital enkätundersökning där vi utan praktiska kringarrangemang kunde nå ut till fler informanter än om vi hade valt intervjuer som metod. I det som följer redovisar vi de modersmålstalande studenternas svar på enkätundersökningen.

\subsection{De modersmålstalande studenternas perspektiv - metod, informanter och material}

Enkäten inleddes med frågor som syftade till att kartlägga LI-studenternas profil och avslutades med två öppna frågor. I den första delen frågade vi efter kön, typ av kurs (campus eller distans), födelseland, första språk samt föräldrarnas modersmål, formella språkkunskaper (skolgång), kontakt med modersmålet och varför informanten valt att studera sitt modersmål på universitetet. Här använde vi oss av fasta svarsalternativ. De två öppna frågorna handlade om huruvida studierna vid ett svenskt lärosäte hade motsvarat informantens förväntningar och hur denne upplevt att studera tillsammans med L2-inlärare. Enkäten utformades som ett Google-formulär, som var lätt att skicka ut direkt till informanterna via e-post och som genererade svarsstatistik automatiskt. För att ta del av enkäten i sin helhet, se appendix I.

Vi sökte informanter som uppfyllde kriterierna att vara infödda talare av franska, spanska eller tyska, att ha kommit till Sverige i vuxen ålder och att vid undersökningstillfället bedriva studier på grundutbildningsnivå (grundkurs, fortsättningskurs eller kandidatkurs) i sitt modersmål vid ett svenskt lärosäte. För att förvissa oss om att enkäten ställdes till studerande som uppfyllde dessa kriterier tog vi hjälp av lärarkollegor vid fyra olika svenska lärosäten med stor geografisk spridning. Urvalet var alltså ett målstyrt bekvämlighetsurval (Trost, 20I2, s. 3I). ${ }^{9}$

De potentiella informanter som vi kom i kontakt med fick sig enkäten tillskickad elektroniskt, med en inledande förklaring av undersökningens syfte, där vi klargjorde att det var frivilligt att delta och att vi garanterade anonymitet. Av de 26 personer som vi skickade enkäten

9 För att nå potentiella informanter valde vi att från början välja ut informanter med rätt profil, en metod som skulle ge färre men för undersökningen mer värdefulla svar än om vi hade skickat den till alla studerande i de aktuella språken. 
till svarade I4. Från dessa I4 tog vi bort två som inte helt uppfyllde kravprofilen. Kvar blev I2 informanter. Även om en större mängd hade varit önskvärd bedömer vi att de svar vi fick in var tillräckligt varierade och fylliga för att tjäna vårt syfte att komplettera undersökningen av lärarperspektivet. Vi kunde notera att flertalet tillfrågade LI-studenter reagerade positivt på att få delge någon sina erfarenheter och uppgav att de var angelägna att få ta del av resultaten av undersökningen.

\section{Högutbildade blivande lärare med starka band till modersmålet}

Nio av de I2 deltagarna i undersökningen är kvinnor och åtta läser på campus medan fyra läser på distans. Fem läser franska, fem spanska och två tyska. Av de I2 respondenterna hade hela åtta studerat upp till och med universitetsnivå i fransk-, spansk- eller tyskspråkigt land. Två av dem hade läst till och med gymnasiet medan två svarade "något annat" på frågan om tidigare studier. Det rör sig alltså om en påfallande högutbildad grupp där merparten är kvinnor.

Vidare ville vi ringa in hur mycket informanterna använder sitt modersmål i vardagen med frågorna "Talar du ditt modersmål utanför studierna?" och "Har du kontakt med släktingar eller vänner som talar ditt modersmål?". Här uppgav en majoritet av de svarande att de talar sitt modersmål dagligen (nio personer), medan två angav "mer än en dag i veckan" och en svarade "mera sällan", och majoriteten har daglig kontakt med släkt och vänner på målspråket (sju personer). Det betyder att de flesta i gruppen upprätthåller en aktiv kontakt med sitt modersmål även utanför studierna.

På frågan "Varför valde du att läsa ditt modersmål på universitetet?" kunde respondenterna fylla i flera svarsalternativ. Merparten svarade att de ville bli lärare i sitt språk, några på grundskolenivå men de flesta på gymnasiet (åtta av I2). Tre personer hade övervägt forskarstudier i språket och två kunde också tänka sig att bli översättare. Ingen uppgav sig läsa i väntan på en annan utbildning eller bara därför att det är roligt. Vi ställde även en följdfråga till dem som tänker sig en lärarkarriär, nämligen om de vet vilka krav som ställs på svenskkunskaper i lärarutbildningen. Att vi ställde denna fråga beror på att det förefaller av yttersta vikt att framtida språklärare inom det svenska skolsystemet är medvetna om kravet på att kunna anlägga ett kontrastivt perspektiv i undervisningen och på att använda svenska i kommunikation med föräldrar och kollegor. Sex av de informanter som vill bli lärare uppger att de är medvetna om svenskkraven och tre att de tänker ta reda på mer.

\section{Mestadels infriade förväntningar och en positiv syn på studierna}

Den första av enkätens öppna frågor var "Motsvarar de universitetskurser i ditt modersmål du hittills gått dina förväntningar?". Här kan svaren delas in i tre kategorier: sex personer tycker att studierna helt motsvarar eller överträffar förväntningarna, tre tycker att förväntningarna delvis infriats, medan två svarar nej på frågan..$^{10}$

De respondenter som uppger att studierna motsvarar förväntningarna svarar genomgående kortfattat utan att vidare kommentera sitt svar. Den grupp som svarar att studierna till viss del motsvarar vad de tänkt sig ger mer utförliga och nyanserande svar. De uppger att

- utbildningen är bra även om man som student måste vara mycket självständig;

- lärarkompetensen i något fall brister;

10 En av informanterna tycks ha missförstått frågan, varför vi inte tar med dennes svar. 
- de fått andra kunskaper än de förväntade, framför allt vad gäller det kontrastiva, vilket varit positivt. Någon skriver: "Jag har också fått fundera över hur man skulle översätta från [modersmålet] till svenska, och det är intressant för mig. I de kurserna i svenska som jag har gått har man bara undervisat i svenska. Motsvarighet i sitt eget modersmål har man inte tänkt så mycket [på], men jag märkte tydligt nu att det var viktigt och att jag hade saknat den delen.”

I den grupp som inte tycker att studierna motsvarat deras förväntningar finns två studenter som menar att modersmålstalande studenter borde få tentera kurserna utan att delta i undervisningen eftersom studierna är slöseri med tid.

Den andra öppna frågan var "Hur upplever du att studera ditt modersmål tillsammans med personer som har det som främmande språk?". Av svaren går att utläsa att en liten grupp, fyra personer, upplever det som mest negativt, medan en större grupp, sju stycken, upplever det som övervägande positivt. Ett svar går inte att tolka i någondera riktningen.

Bland de svar som hamnat i den första gruppen märks det korta "Jobbigt", samt svaret från en informant som var medveten om att hen som LI-student hjälpte läraren att göra diskussionerna intressantare för L2-studenterna, men som för sin personliga del upplevde studierna som förlorad tid: "We helped the teachers, the discussion get[s] richer and it is probably helpful for the främmande students. But I am working IOO\% beside, so I lost my time." I den andra gruppen, med en övervägande positiv inställning, märks utsagorna att det är intressant och lärorikt om bara L2-studenterna vågar prata. Detta svar ska jämföras med iakttagelsen i Edstrom (2007), att vissa LI-studenter tror att de hämmar L2-studenterna medan L2-studenterna överlag är tillfreds med dynamiken i klassrummet. Någon LI-talare föredrar vidare att ha modersmålstalande lärare eftersom de svenska lärarna enligt denne ibland gör språkfel och ger oklara instruktioner. Två informanter svarade att grundkursen var långsam men att det på fortsättnings- och kandidatkursen krävs mycket även av LI-studerande. Båda två betonar att det varit givande att som blivande lärare följa L2-studenternas utveckling och iaktta de svårigheter som dessa har i sin språkinlärning. Detta är något som framkommer i såväl Edstrom (2007) som López García (2017): att studera universitetskurser tillsammans med L2-inlärare ger ett utifrånperspektiv på det egna modersmålet.

Den bild som framträder är att de LI-studenter som deltog i enkätundersökningen har en förhållandevis positiv attityd till sina språkstudier. Merparten avser att bli lärare i sitt modersmål i svenskt skolväsende och accepterar att de måste bedriva universitetsstudier i språket. Ett fåtal ser sig förvisso som ett slags nettobetalare som ger mer till utbildningen än vad de själva får tillbaka. Dessa hade gärna sparat tid genom att få tillgodoräkna sig sin reella kompetens. Det är dock lika många som nämner att det är givande att som blivande lärare följa L2-studenternas språkutveckling, och en respondent betonar att språkstudierna ger en unik möjlighet att träna den kontrastiva färdigheten.

\section{AVSLUTANDE DISKUSSION}

Till skillnad från i exempelvis USA, där andelen arvspråkstalare i vissa språkkurser - främst spanska - sedan länge varit stort och stadigt växer (se t.ex. Valdés, 1995; 2005; Edstrom, 2007; López García, 20I7), och där även antalet modersmålstalande studenter i språkutbildning är större, finns det vid svenska lärosäten inga särskilda spår inom språkutbildningarna som är särskilt avsedda för arvspråkstalare eller LI-talare. Därav följer att dessa båda kategorier införlivas i de ordinarie kurserna, som tar sin utgångspunkt i de behov som L2-studenterna har. 
I vår undersökning av hur universitetslärare hanterar den komplexa undervisningssituation som uppstår i språkgrupper där den språkliga kompetensen kraftigt varierar på grund av sammansättningen med inslag av modersmålstalare i främmandespråkskurserna baserar vi oss på utsagor inhämtade via djupintervjuer med sex universitetslärare. Denna studie kompletteras av en enkätundersökning där I2 modersmålstalande studenter som studerar sitt eget språk anger vilka motiv de har till att läsa språket vid ett svenskt lärosäte och hur deras erfarenhet av studierna ser ut. Underlaget är relativt litet och de utsagor vi tagit del av är individspecifika och inte generaliserbara. Emellertid pekar de på några tendenser som vi menar är värda att lyfta fram.

Den första tendensen är att lärarna överlag tycker att LI-studenterna är ett positivt inslag i språkutbildningen. Även om de stundtals upplever att det är en utmaning att tillse att alla studenter får komma till sin rätt i klassrummet upplever de generellt LI-studenterna mer som en tillgång än som en svårighet eller utmaning. Det finns en medvetenhet om risken att LIstudenterna kan komma att dominera genom sina bättre språkfärdigheter, men på det hela taget bekymrar den varierande språkliga kompetensen universitetslärarna i betydligt mindre grad än vad som var fallet med gymnasielärarna i Seiler-Holmers (2014) eller Svenssons (2017) studier. Den vanliga uppfattningen att LI-studenterna hämmar L2-inlärarna, speciellt när det gäller att ta ordet i klassrummet, tas upp till diskussion av lärarna i intervjuerna. Deras erfarenhet är dock att rädslan hos L2-studenterna är övergående, att de snarare tycks dra nytta av modersmålstalarna, eller att det är andra faktorer som spelar lika stor roll för de tillbakadragna studenternas muntliga produktion som närvaron av LI-talare, inte minst gruppstorlek. Flera lärare pekar på att LI-studenterna tjänar som motorer i undervisningen och hjälper lärarna att göra undervisningen dynamisk, särskilt vad gäller att hålla igång samtal och diskussioner. Detta nämndes också i en av enkäterna där en LI-student uppgav sig ha märkt att hen hjälpte läraren i undervisningen och därmed gagnade L2-studenterna, men inte sig själv.

Flera lärare påtalade risken att som lärare dras med av LI-talarnas bättre språkfärdighet och, oftast, större allmänorientering inom det studerade språkområdet. En utmaning som hänger ihop med detta är att det kan vara lätt att ta för givet att LI-talarnas akademiska färdigheter även de är större. En av lärarna problematiserade detta och menade att det tvärtom kan vara så att LI-studenterna, liksom för övrigt även arvspråkstalarna, har större behov av stöd när det gäller att utveckla akademiska kunskaper och förmågor, som att förstå språkliga strukturer på ett teoretiskt plan eller skriva stringenta analytiska texter. För dessa grupper tillkommer ofta en dimension som L2-studenterna inte har att brottas med, nämligen självbilden. Att inte få bästa resultat på olika uppgifter relaterade till modersmålet, och kanske se kurskamrater med sämre språkfärdigheter klara dem, kan bli ett slag mot självkänslan och i förlängningen mot ens identitet.

En annan tydlig tendens var att samtliga lärare var medvetna om att de undervisar för L2studenterna och att de skulle undvika att anpassa sig efter LI-nivån. Enkätsvaren visar att LIstudenterna trots detta överlag har en positiv attityd till sina studier. Några av dem som ska bli lärare noterar att det är lärorikt att se vilka svårigheter de svenska studenterna har när de lär sig språket i fråga. Detta överensstämmer med de svar som Edstrom (2007) samlade in i en avancerad språkgrupp i USA, där LI-studenterna uppgav denna indirekta kunskap som mycket viktig för deras framtida yrkesutövning. Även om någon respondent $i$ vår undersökning menade att det hade varit fördelaktigt att få möjlighet att tentera av kurserna i modersmålet för att snabbare kunna ta ut en examen hade majoriteten inga invändningar, utan svaren tyder på att de accepterar studierna i det svenska systemet. 
Sammantaget pekar vår undersökning mot att universitetslärarna i språk ställs inför vissa utmaningar vad gäller gruppdynamik men att de främst ser modersmålstalande studenter som en tillgång i klassrummet.

Som tidigare påpekats är detta en liten studie som i framtida forskning med fördel kunde utökas till att omfatta fler informanter. Det hade också varit relevant att inkludera L2studenternas upplevelse av att studera språk i blandade grupper. Edstrom (2007) har undersökt både LI-studerande, L2-studerande och arvspråkstalare och det skulle vara givande att göra detsamma i en svensk kontext.

\section{FÖRFATTARPRESENTATION}

Gudrun Seiler-Holmer är M.A. i sinologi, B.Sc. i socialantropologi och legitimerad gymnasielärare i kinesiska och spanska. Hennes forskningsintresse ligger inom didaktik och språkinlärning både på gymnasie- och högskolenivå, med särskilt fokus på undervisningens kvalité och påverkansfaktorer för språkinlärning. Idag arbetar hon som gymnasielärare i spanska.

Ingela Johansson är lektor i spanska vid Lunds universitet. Hon forskar inom litteraturförmedling, litterär översättning och didaktik, främst på högskolenivå. Hon har en bakgrund som gymnasielärare.

\section{REFERENSER}

Abdi, K. (2009). Spanish heritage language learners in Canadian high school Spanish classes: negotiating ethnolinguistic identities and ideologies. Networked Digital Library of Theses \& Dissertations. https:// www.library.ucsb.edu/node/3637.

Alarcón, I. (2010). Advanced heritage learners of Spanish: a sociolinguistic profile for pedagogical purposes. Foreign Language Annals, vol. 43, n:o 2, s. 269-288.

Blyth, C. S. (red.) (2003). The sociolinguistics of foreign language classrooms: contributions of the native, the near-native, and the non-native speaker. Boston: Thomson/Heinle.

Bryman, A. (2011). Sambällsvetenskapliga metoder. Stockholm: Liber.

Edstrom, A. (2007). The mixing of non-native, heritage, and native speakers in upper-level Spanish courses: a sampling of student opinion. Hispania, 90(4), s. 755-768. DOI: 10.2307/20063610.

Elder, C. (2000). Outing the native speaker. The problem of diverse learner backgrounds in 'foreign' language classrooms - an Australian case study. Language, Culture and Curriculum, 31(1), s. 86-108. DOI: $10.1080 / 07908310008666591$.

Ellis, R. \& Shintani, N. (2014). Exploring language pedagogy through second language acquisition research. London: Routledge.

Europeiska kommissionen (2008). Meddelande frän kommissionen till Europaparlamentet, europeiska ekonomiska och sociala kommittén samt regionkommittén. Flerspråkighet: en tillgång för Europa och ett gemensamt atagande. KOM (2008) 566 slutlig http://ec.europa.eu/transparency/regdoc/rep/1/2008/ SV/1-2008-566-SV-F1-1.Pdf.

Katz, S. (2003). Near-native speakers in the foreign-language classroom: the case of Haitian immigrant students. I: Blyth, C. S. (red.) (2003). The Sociolinguistics of foreign language classrooms: contributions of the native, the near-native, and the non-native speaker. Boston: Thomson/Heinle.

López-García, M. P. (2017). La enseñanza del español a hablantes de herencia en inmersión parcial y total: factores eficaces del aprendizaje en aulas heterogéneas /The teaching of Spanish to heritage speakers in partial and total immersion: effective factors of learning in heterogeneous classrooms. Tejuelo: Didáctica de la lengua y la literatura, Vol. 26, s. 113-142 (2017), 113. DOI: 10.17398/1988-8430.26.113.

Polinsky, M. \& Kagan, O. (2007). Heritage languages: in the 'wild' and in the classroom. Language and Linguistics Compass 1(5): 368-395.

Seiler-Holmer, G. (2014). L1-inlärare i L2-klassrummet. En intervjustudie med gymnasielärare i moderna språk. Examensarbete, Lunds universitet och Högskolan Kristianstad, Utbildningsvetenskapliga institutionen. 


\section{Ingela Johansson och Gudrun Seiler-Holmer}

SFS (2011:185). Skolförordning. Stockholm: Justitiedepartementet. http://www.riksdagen.se/sv/dokument-lagar/dokument/svensk-forfattningssamling/skolforordning-2011185_sfs-2011-185\#K9.

Svensson, A. (2017). The challenge of teaching English in a heterogeneous classroom. Educare - Vetenskapliga skrifter, 17(2): 56-80.

Torres, J., Pascual y Cabo, D., Beusterien, J. (2017). What's next?: heritage language learners shape new paths in Spanish teaching. Hispania, v 100 n5, s. 271-276. DOI: 10.1353/hpn.2018.0066.

Trost, J. (2012). Enkätboken. Lund: Studentlitteratur.

Valdés, G. (1995). The teaching of minority languages as academic subjects: pedagogical and theoretical concerns. The Modern Language Journal, v 79 n3 s. 299-328. DOI: 10.2307/329348.

Valdés, G. (2005). Bilingualism, heritage language learners, and SLA research: opportunities lost or seized? The Modern Language Journal, v 89 n3 s. 410-426. https://doi.org/10.1111/j.1540-4781.2005.00314.x.

Weaver, R. R. \& Qi, J. (2005). Classroom organization and participation: college students' perceptions. The Journal of Higher Education, Vol. 76, No. 5 (Sep.-Oct., 2005), s. 570-601. https://www.jstor.org/stable/3838840. 
APPENDIX I

\section{Enkät för studenter som läser franska/spanska/tyska vid universitetet VT18}

- Syftet med denna enkät är att bidra till en större undersökning som handlar om modersmålstalare som läser franska, spanska och tyska som främmande språk vid svenska universitet.

- Obs! Detta är en anonym enkät, därför behöver du inte uppge ditt namn! Svaren kommer inte att kopplas till enskilda personer och allt kommer att göras för att säkra din personliga integritet.

- Du får gärna svara på ditt eget modersmål, och helst så utförligt som möjligt på de öppna frågorna.

- Vi vill ha ditt svar senast den 28 februari!

Vi är tacksamma för din medverkan! Den är mycket värdefull.

* Required

I. Kön*

Mark only one oval.

- Kvinna

Man

Vill inte ange

2. Typ av universitetskurs*

Mark only one oval.

- Campuskurs

- Distanskurs

- Blandad

3. Var är du född? *

Är du född i Sverige eller i annat land? Uppge gärna vilket.

4. Vilket är ditt första språk?*

(ditt modersmål, språket du lärde dig när du var liten)

5. Vilket/-a modersmål har dina föräldrar?

6. Vilka är dina formella förkunskaper i det språk du studerar på universitetet?*

Välj det som stämmer bäst på dig eller skriv in eget svar efter "Något annat".

Mark only one oval.

- Steg 3 i svensk skola

Steg 4 i svensk skola

- Steg 5 i svensk skola

- Steg 6 i svensk skola 
- Till och med grundskola i fransk-/spansk-/tyskspråkigt land

- Till och med gymnasieskola i fransk-/spansk-/tyskspråkigt land

- Till och med universitetsstudier i fransk-/spansk-/tyskspråkigt land

- Något annat

7. Talar du ditt modersmål utanför studierna?*

Mark only one oval.

$\circ$ dagligen

- mer än en gång $\mathrm{i}$ veckan

$\circ$ mera sällan

$\circ$ aldrig

8. Har du kontakt med släktingar eller vänner som talar ditt modersmål?* Mark only one oval.

$\circ$ dagligen

- mer än en gång i veckan

- mera sällan

$\circ$ aldrig

9. Varför valde du att läsa ditt modersmål på universitetet?*

Välj det som stämmer bäst in på dig. Det är möjligt att ange flera svar. Du kan också skriva ett eget svar efter "Något annat".

Check all that apply.

- Det är bra att ha ett formellt intyg på att jag kan språket.

- Det är roligt.

- Jag läser språket medan jag väntar på att komma in på den utbildning jag egentligen vill gå.

- Jag vill bli grundskollärare med mitt modersmål som ett ämne.

- Jag vill bli gymnasielärare med mitt modersmål som ett ämne.

- Jag vill bli översättare och arbeta med mitt modersmål.

- Jag tänker mig en framtid på universitetet och vill doktorera i mitt modersmål.

- Något annat:

Io. Om du vill bli lärare, känner du till vilka krav som ställs på språkkunskaper $i$ svenska?*

Mark only one oval.

$\circ \mathrm{Ja}$

$\circ \mathrm{Nej}$

- Inte än, men jag kommer att informera mig.

II. Om du svarade ja på föregående, hur eller av vem fick du informationen? 
12. Motsvarar de universitetskurser i ditt modersmål du hittills har gått dina förväntningar? Förklara så utförligt som möjligt. Du kan gärna svara på ditt eget modersmål! *

13. Hur upplever du att studera ditt modersmål tillsammans med personer som har det som främmande språk? Du kan gärna svara på ditt eget modersmå!! * 